\title{
Occupational Role Identity of Women Academic Librarians
}

\section{Pamela J. Cravey}

With advanced microcomputer technology, distributed access to bibliographic and textual data, and a cultural climate of disdain for the traditional, the professional demands placed upon academic librarians are enormous. And yet, women continue to embrace this professional subspecialty. A national survey examined the occupational role identity of female academic librarians. Personal, demographic, and job data were collected. In addition, a test for orientation to the occupational role and a sex-role orientation test were administered. Statistical analyses ranged from cross-tabulations to multiple discriminant analyses. Academic librarians were found to hold a positive and unique occupational role identity.

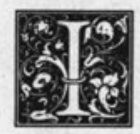

n 1983 Kathleen Heim noted, in The Status of Women in Librarianship, that librarianship is still a field that is numerically dominated by women. ${ }^{1}$ In an era in which so many occupational choices are available to women, what is there about academic librarianship that continues to make it a viable career option for women? The answer to this question lies in the occupational role identity of academic librarians.

\section{IDENTITY AND IMAGE}

To the general public, the word librarian conjures up either an outmoded stereotypical picture of a "little old lady with a bun" or a rigid personality type. In other words, regardless of what librarians actually do, the profession labelled "librarian" evokes a single occupational image. Pauline Wilson criticized librarians for spending inordinate amounts of time agonizing over their image. ${ }^{2}$ Similarly, Patricia Glass Schu- man indicated librarians should be "spending less time talking to ourselves, about ourselves; spending less time discussing the inner workings of our libraries. . . [and should]. . .effectively present the potential of American librarianship." ${ }^{\prime 3}$

What is the difference between occupational identity and occupational image? Occupational image is the collective perception of what a person is in the occupation. It is formed by the opinions of others, and like a stereotype, it seems to be unresponsive to change. Its impact is felt in areas such as recruitment and occupational status and prestige. ${ }^{4,5}$ Occupational identity, on the other hand, is self-perception. Occupational identity determines how librarians see themselves in relation to librarianship-to the functions as well as to the clientele. Within librarianship there exists a subculture of subspecialties. Some critics have hypothesized that each librarian subspecialty may also have a unique oc-

Pamela J. Cravey is associate professor and head of the Circulation Department, Pullen Library, Georgia State University, Atlanta, Georgia 30303. 
cupational identity. For example, Beverly P. Lynch described the occupational identity of the academic librarian as being closely allied to that of teacher and researcher. ${ }^{6}$

Most of the literature about librarians, however, is focused on their image, rather than occupational identity. This literature has described the image of the librarian from the users'/observers' viewpoint, by studying library school students, or from a purely demographic and socioeconomic perspective. ${ }^{7-9}$ In some instances the librarian type was described after comparing a limited number of traits held by library school students to some form of a general population. ${ }^{10}$ Generally, "image" is used as a euphemism for "stereotype." For librarians this image traditionally has been negative.

\section{The project was aimed at understand- ing women librarians through an analysis of some of the components of the total occupational role.}

In reaction to the stereotype-the external view of the profession-the librarian's own occupational self-perception has suffered from internalizing the negative impression. For example, Wilson's content analysis of nearly 500 documents written about the librarian stereotype from 1921 to 1978 concluded that the negative librarian image has pervaded both professional librarian as well as nonlibrarian literature. ${ }^{\text {"Th }}$ This study relates to occupational image rather than to occupational identity. However, two notable studies of the occupational identity of librarians do exist. Both studies considered the occupational subculture of public librarians. Alice I. Bryan's landmark study of public librarians found an anomalous group with no clearly defined professional identity. ${ }^{12}$ Robert B. Clift's study found that librarians underestimated their importance to their clientele. ${ }^{13}$ This undervaluation of professional worth-a result of the pervasiveness of the nega- tive occupational image-was also reported by Rosalee McReynolds and by Locke J. Morrisey and Donald O. Case. ${ }^{14,15}$ Further, a recent study of product/service advertisements in four journals representing four dominant librarian subspecialties found shallow and boring physical and action-role portraits of librarians. ${ }^{16}$ No studies presenting the occupational identity of librarians were identified. In an effort to explain the occupational identity of the librarian from within the profession, a large national survey of professionally committed librarians was conducted in 1986. Funded by the Council on Library Resources, the project was aimed at understanding women librarians through an analysis of some of the components of the total occupational role. These components included personal demographics, orientation to the occupational role, and sex-role orientation. In addition, in order to determine if unique occupational subcultures exist, librarians representing four traditional subspecialties of librarianship-academic, public, school, and special-were sampled. Findings from the study included a picture of the occupational identity of each of the subspecialties. Women practitioners were viewed apart from the question of the occupational image. This paper reports on the occupational role identity of women academic librarians as identified in this national survey.

\section{THE SURVEY}

\section{The Sample}

Nine hundred seventy-seven female librarians representing members of each of these four traditional subspecialties were surveyed. Sample size was determined by projected response rate, sampling procedure, homogeneity of the groups to be studied, and cost. First, the study was designed to analyze responses from 400 librarians - 100 from each subspecialty. In order to offset the projected 40 to 50 percent response rate of typical self-administered questionnaires, the group size was increased. ${ }^{17}$ Second, the project was designed to study members 
of four subspecialties that naturally represent strata of the profession. Because projected variances among these subgroups were of primary interest, a stratified sampling procedure was employed. ${ }^{18}$ Third, because each of the four strata was homogeneous relative to the attributes to be studied, a subgroup sample of 100 was sufficient. ${ }^{19}$ Because records based on gender were not available, each sample subgroup was increased proportionate to the estimated number of men in that subspecialty. Finally, the costs of a larger sample were considered in relation to the expected gain in precision. By using this stratified sample, the study was comparable to a "special" survey of few subgroups. For this method, Seymour Sudman suggested a sample of 200-500. Doubling the sample size would not have significantly increased precision. ${ }^{20}$

Two national associations drew the random samples. The American Library Association supplied a list and mailing labels for samples drawn from the membership rosters of the Association of College and Research Libraries, The Public Library Association, and the American Association of School Librarians. The Special Libraries Association provided the same for the special librarians.

The project was restricted to women for two reasons First, cost precluded use of the larger sample size that would have been necessary to include a representative sample of men. Second, little scholarly attention has historically been given to developing a theory about the unique factors that influence occupational choice for women. ${ }^{21}$ Victor R. Fuchs noted that interest in gender issues relative to occupational choice and economic equality is unequal. ${ }^{22}$ Part of the reason for this unequal treatment is that the issues surrounding an occupational choice are so complex that the literature of several fields is replete with studies. For example, journalists, educators, psychologists, economists, vocational counselors, and sociologists all examine occupational choice. ${ }^{23}$ Studies are regional, cross-cultural, or international. ${ }^{24}$ Study subjects include boys, women, high school students, and junior college students. ${ }^{25}$ Scholars have proposed universal models, subject-specific models, and models that lean toward separate criteria for different types of people. ${ }^{26}$ Some studies are concerned with occupational aspirations, aspirations in relation to choice, and aspirations related to outcome. ${ }^{27}$ In addition, choosing an occupation has been dichotomized in the literature as normative, adventitious, or purposive.$^{28}$ Each discipline further divides its literature into three or four main categories. For example, Samuel H. Osipow identified four theoretical frameworks - trait-factor, self-concept, sociological, and personality theories. ${ }^{29}$ Ronald M. Pavalko characterized three different approaches to the study of occupational choice: the rational decision making approach, the fortuitous approach, and the sociocultural influence approach. ${ }^{30}$

\section{Women continue to remain un- derrepresented in studies that focus either on overall occupational choice or on choice of an occupational sub- specialty.}

Researchers and theorists have wrestled with the development of an overall theoretical framework for analyzing occupational choice. However, a confounding variable hindering the development of such a theory is the possibility that multiple gender-specific theories must be developed..$^{31}$ These writers argue that women are not free to make meaningful choices and that the choices made may reflect labor market insensitivities, socialization, and childrearing responsibilities and emotional involvements. ${ }^{32}$ Consequently, while occupational choice theories abound, no unified theory yet exists. Further, women continue to remain underrepresented in studies that focus either on overall occupational choice or on choice of an occupational subspecialty. ${ }^{33}$ This study was restricted to women with the hope that the findings relative to oc- 
cupational identity would contribute to the overall literature of occupational choice for women.

\section{The Questionnaire}

The librarian's occupational role identity was studied through the use of a self-administered, three-part mailed questionnaire that queried subjects about themselves, their assessments of job-related attributes, and their views on sex roles. The first and second parts of the questionnaire were developed by the researcher.

The first part of the questionnaire was an overview of the librarian's personal occupational and social history. It included thirty multiple-choice and openended questions about demographics, economics, career choices, career mobility, nuclear family, and family orientation, among others.

The second part of the questionnaire was a twenty-question bipolar semantic differential. It was developed using the domain sampling model. The semantic differential technique is used to measure both the meanings of things and attitudes toward things. It is a flexible measure that can adapt to a variety of concepts and formats. The semantic differential technique is frequently used to measure the differences in meaning of the same concept among groups. Bipolar scales are used to measure the differences, and when factor analyzed, the differences traditionally yield the three dimensions of "evaluation," "potency," and "activity." ${ }^{34}$ While the semantic differential technique has its critics, in occupational research it can be a way of assessing the saliency of a concept among groups.$^{35}$ To that end, two small surveys of practicing librarians were conducted to establish the poles for the semantic differential portion of the questionnaire. The poles were to be relative to the librarian occupational role. In the first small survey, forty librarians suggested adjectives to complete the sentence: "In my role as an academic librarian I think I am:

The 176 adjectives suggested by these practitioners were tested for bidirectionality in several thesauri and were culled by frequency distributions to twenty of the most representative. Then forty additional librarians were contacted in the second small survey to provide "librarian role" antonyms to these twenty "librarian role" adjectives. Librarians (twenty from each subspecialty) were selected for the adjective and antonym assemblage phases of the project to assure both scale poles would represent the salient aspects of the librarian role and cover the semantic space relative to librarianship. ${ }^{36}$ Page placement on the final questionnaire was determined by a criss-cross first-to-last last-to-first strategy.

The third part of the questionnaire measured the sex-role orientations of the librarians. The Short Form of the Personal Attributes Questionnaire (PAQ), developed by Janet T. Spence, Robert Helmreich and Joy Stapp, was used with Dr. Spence's permission. The Short Form PAQ is a twenty-four-item bipolar selfreport instrument used to differentiate stereotypically between the sexes. ${ }^{37}$ It also tests for masculinity and femininity. The PAQ was selected to measure sexrole orientation because it "is made up of items describing characteristics that are not only commonly believed to differentiate the sexes but on which men and women tend to report themselves as differing.... The stereotypic characteristics included on the PAQ are favorably regarded, socially desirable attributes." $^{\text {38 }}$ Sex-role orientation was selected as an important domain of occupational identity because of the numerical dominance of women in the profession and the service relationship to the clientele. George Ritzer indicated that these attributes and "the seeming fit between occupational and sex roles" conspire to oppress professions in which women are numerically dominant. ${ }^{39}$

\section{Data Collection}

Questionnaires were mailed with cover letters on university stationery. The letter mentioned the researcher's current position as a librarian and implored participation as a colleague. An 
addressed, stamped, return envelope and a response postcard were also enclosed. There were no identifying marks or numbers on the questionnaires or on the return envelopes. All responses were anonymous. A reminder postcard was sent after two weeks; three weeks later another copy of the questionnaire was mailed. The overall response rate was 84.5 percent.

\section{Responses}

Responses were received from librarians practicing in all states except Idaho; and from the District of Columbia, Puerto Rico, and Canada. One hundred seventy-nine responses were from academic librarians - a response rate of 83.6 percent. Findings will be presented according to each of the three role identity components studied.

\section{ACADEMIC LIBRARIANS}

\section{Personal Demographics}

The first part of the questionnaire collected background information on the librarian respondents. Frequency distributions yielded little variety in either the entire sample or in the academic librarian sample relative to most of the personal demographic attributes. For example, the mean age of the total sample was 43.8 years; the mean age for the academic librarians was 43.7 years. Table 1 summarizes some of the nominal data about academic librarians and percentages relative to the total sample. ${ }^{40}$

A thumbnail sketch of the "average" academic librarian revealed a white, protestant, married, middle-aged woman with no children. She is the progeny of professional parents. This librarian began her career at age twentythree after receiving an M.L.S. in 1971 from a library school in the east-probably Simmons College, Columbia University, or Rutgers. She has practiced academic librarianship for eleven years. Exactly half of the academic librarian respondents had practiced in other librarian subspecialties as well-usually special librarianship-but preferred academic librarianship because they found it challenging ( 15 percent) and they liked the academic environment (15 percent).

\section{A thumbnail sketch of the "average" academic librarian revealed a white, protestant, married, middle-aged woman with no children.}

Academic librarians were satisfied with their career choice; 69 percent indicated they would again select librarianship as a career. When asked why, the response most often cited was "I like it!" Approximately 75 percent of the academic librarians would again select academic librarianship as a subspecialty. Conversely, 30 percent of the academics indicated they would not select librarianship as a career again. One-fourth of these librarians cited pay as the reason. Among these women, most cited law and teaching equally as the careers they would pursue instead of librarianship. Again, pay was the predominant reason (20 percent) for these choices.

Academic librarians are professionally involved and committed to continuing education. Thirty-nine percent of them had degrees or training beyond the library degree. This training included additional coursework, certification programs, and additional or advanced degrees. Second master's degrees (completed and in process) were reported by 40 percent of the academics with advanced training. In addition, over one-half of the academic librarians belonged to two or three professional associations. By way of comparison, only 13 percent of the public librarians cited training beyond the library degree. However, public librarians (71.5 percent) indicated more associational memberships than the other three subspecialties.

\section{Orientation to the Occupational Role}

The second part of the survey used the semantic differential technique to assess the respondents' orientation to the occupational role of librarian. The librarians were asked twenty Likert-style ques- 
TABLE 1

OVERVIEW OF ACADEMIC LIBRARIANS

\section{Number}

Percent of Academic Librarians

(Percent of Total Librarian Sample)

\begin{tabular}{lccccc}
\hline Ethnic Origin & Asian & Black & Hispanic & White & Other \\
\hline & 4 & 4 & 2 & 158 & 2 \\
& 2.4 & 2.4 & 1.2 & 92.9 & 1.2 \\
& $(1.6)$ & $(3.1)$ & $(0.9)$ & $(93.4)$ & $(1.0)$ \\
\hline Religion & Catholic & Jewish & Protestant & Other & \\
& 29 & 8 & 85 & 38 & \\
& 18.1 & 5.0 & 53.1 & 23.8 & \\
& $(18.9)$ & $(6.5)$ & $(56.2)$ & $(18.5)$ & \\
\hline
\end{tabular}

\begin{tabular}{lccccc}
\hline Marital Status & Divorced & Married & Never Married & Separated & Widowed \\
\hline & 17 & 93 & 59 & 0 & 3 \\
& 9.9 & 54.1 & 34.3 & 0.0 & 1.7 \\
& $(13.4)$ & $(58.0)$ & $(25.3)$ & $(0.3)$ & $(3.1)$ \\
\hline Offspring & Yes & No & & & \\
\hline & 75 & 97 & & & \\
& 43.5 & 56.4 & & & \\
\hline
\end{tabular}

Father's

Occupation

Blue Collar Craftsmen

Farming

White Collar Not employed

$\begin{array}{ccccc}19 & 21 & 8 & 116 & 0 \\ 11.6 & 12.8 & 4.9 & 70.7 & 0.0 \\ (15.4) & (11.1) & (6.3) & (66.8) & (0.5)\end{array}$

Mother's

Occupation

Blue Collar Craftsmen

Farming

White Collar Not employed

\begin{tabular}{lccccc}
\hline & 13 & 2 & 3 & 80 & 71 \\
& 7.7 & 1.2 & 1.8 & 47.3 & 42.0 \\
& $(10.9)$ & $(0.5)$ & $(0.9)$ & $(47.1)$ & $(40.8)$ \\
\hline Library School & East & Midwest & North & South & Other \\
\hline & 57 & 53 & 35 & 23 & 2 \\
& 33.5 & 31.2 & 20.6 & 13.5 & 1.2 \\
Where & $(34.4)$ & $(28.8)$ & $(20.0)$ & $(15.0)$ & $(1.7)$ \\
\hline Practicing & East & Midwest & North & South & Other \\
\hline & 51 & 43 & 43 & 30 & 6 \\
& 29.5 & 24.8 & 24.8 & 17.4 & 3.5 \\
& $(33.3)$ & $(23.9)$ & $(22.6)$ & $(16.8)$ & $(3.5)$ \\
\hline
\end{tabular}




\section{Number}

Percent of Academic Librarians

(Percent of Total Librarian Sample)

\begin{tabular}{lcccc}
\hline $\begin{array}{l}\text { Would Select } \\
\text { Librarianship Again }\end{array}$ & Yes & No & Uncertain & \\
\hline & 118.0 & 49.0 & 4.0 & 2.3 \\
& 69.0 & 28.7 & $(2.1)$ & \\
\hline Practiced in Other & $(72.1)$ & $(25.8)$ & & \\
Subspecialties & Yes & No & & \\
\hline & 84.0 & 84.0 & & \\
& 50.0 & 50.0 & & \\
\hline Additional Training & $(49.7)$ & $(50.3)$ & & \\
\hline & Yes & No & & \\
& 67.0 & 103.0 & & \\
\hline Professional Association & 39.4 & 60.6 & & \\
Memberships & $(32.3)$ & $(67.7)$ & & \\
\hline & & & & \\
& One & Two & & \\
& 21.0 & 52.0 & 54.0 & $(13.0)$ \\
\hline & 12.2 & 30.2 & 31.4 & $(27.6)$ \\
\hline
\end{tabular}

tions that began: "In my role as a librarian in my current subspecialty I am ...." Several scholars suggest that situating survey questions in a specific role context allows the role to emerge, permits meaningful response options, and assures the stability of responses over long periods of time. ${ }^{41} \mathrm{On}$ all but one question, the librarians did respond in their professional role. However, the nurturing/businesslike pair evoked many emotional handwritten comments and admonishments to the researcher. Clearly this question was extremely relevant to these women's current situation and emotional context.

Pay seemed to be an issue and was the factor most likely to cause them to move to another profession.

In the overall sample, the librarians' self-perceptions were extremely high; responses generally clustered around the two most favorable response options. While the academic librarians' self-perceptions were extremely high, they were more moderate than those of the group as a whole. Table 2 displays the frequency distributions for the academic sample with all the orientation to the occupational role scales arranged in the same direction-most unfavorable to most favorable. Although the most favorable selection might not reflect a positive work situation (idle/busy), the responses of the academic librarians also clustered around the two most favorable intervals on most scales. In four adjectival pairs, the academic librarians' modal responses were different from the modal responses of the group as a whole.

Several statistical tests were performed on the adjectival pairs. First, factor analysis tested for dimensionality. Generally, factor analysis will yield three factors. $^{42} \mathrm{~A}$ visual inspection of the twenty adjectival pairs indicated three 
TABLE 2

\section{FREQUENCY DISTRIBUTIONS FOR ORIENTATION TO THE OCCUPATIONAL ROLE} OF ACADEMIC LIBRARIAN (ADJUSTED FREQUENCY PERCENT)

\begin{tabular}{llll}
\hline unsympathetic & $.6 / .0 / 4.1 / 17.1 / 47.6 / 30.6 /$ & $\mathrm{N}=170$ & sympathetic \\
*superfluous & $.0 / 2.9 / 13.4 / 39.5 / 37.2 / 7.0 /$ & $\mathrm{N}=172$ & indispensable \\
process-orientated & $5.2 / 3.5 / 8.7 / 16.8 / 26.6 / 39.3 /$ & $\mathrm{N}=173$ & service-orientated \\
idle & $.0 / .6 / 1.1 / 3.4 / 24.7 / 70.1 /$ & $\mathrm{N}=174$ & busy \\
unfriendly & $.0 / .6 / .6 / 6.9 / 41.4 / 50.6 /$ & $\mathrm{N}=174$ & friendly \\
"rigid & $.0 / 1.7 / 3.4 / 19.0 / 41.4 / 34.5 /$ & $\mathrm{N}=174$ & flexible \\
pessimistic & $.6 / 4.6 / 14.5 / 24.3 / 38.7 / 17.3 /$ & $\mathrm{N}=173$ & optimistic \\
ignorant & $.0 / 1.1 / 3.4 / 12.6 / 50.0 / 32.8 /$ & $\mathrm{N}=174$ & knowledgeable \\
hindering & $.0 / 1.1 / .0 / 4.6 / 38.5 / 55.7 /$ & $\mathrm{N}=174$ & helpful \\
unimaginative & $.0 / 1.1 / 7.5 / 30.5 / 38.5 / 22.4 /$ & $\mathrm{N}=174$ & creative \\
disorganized & $2.3 / 1.7 / 11.5 / 19.0 / 36.8 / 28.7 /$ & $\mathrm{N}=174$ & organized \\
incompetent & $.0 / 1.1 / 1.1 / 9.2 / 37.4 / 51.1 /$ & $\mathrm{N}=174$ & competent \\
"nurturing & $2.4 / 6.5 / 20.1 / 26.6 / 24.9 / 19.5 /$ & $\mathrm{N}=169$ & businesslike \\
*burned-out & $.6 / 5.2 / 6.9 / 14.9 / 36.8 / 35.6 /$ & $\mathrm{N}=174$ & interested \\
underutilized & $3.6 / 4.8 / 6.0 / 28.6 / 36.3 / 20.8$ & $\mathrm{~N}=168$ & overworked \\
bored & $2.3 / 2.3 / 11.5 / 20.1 / 28.7 / 35.1 /$ & $\mathrm{N}=174$ & challenged \\
clerical & $.6 / 1.2 / 3.5 / 12.1 / 26.6 / 56.1 /$ & $\mathrm{N}=173$ & professional \\
passive & $.0 / 3.4 / 10.3 / 21.8 / 35.1 / 29.3 /$ & $\mathrm{N}=174$ & assertive \\
a "gopher" & $.0 / .6 / 3.5 / 13.9 / 47.4 / 34.7 /$ & $\mathrm{N}=173$ & instructive \\
uncooperative & $.0 / .0 / .6 / 7.5 / 40.2 / 51.7 /$ & $\mathrm{N}=174$ & cooperative \\
\hline
\end{tabular}

Modal response for the overall sample of librarians (highlighted in bold).

* The modal response of the academic librarians differs from the modal response of the entire sample.

factors could have emerged. However, only one factor did emerge (factor loadings ranged from .824 to .969). Consequently, a factor analysis that forced three factors was performed. Factor 1, however, accounted for $94.4 \%$ of the total variance (eigenvalue $=16.13744$ ) and confirmed the unidimensionality of the data. Second, a one-way analysis of variance was performed on all twenty adjectival pairs. Ten were significant. Two of the four pairs in which the academic librarians' modal responses differed from those of the group as a whole (rigid/flexible and nurturing/ businesslike) were significant. The results are presented in table 3 and table 4 . Further, for the original twenty pairs, Scheffe's a posteriori contrast measure was used to determine pairwise differences. At the
.05 level, both pairs that had modal responses below those of the entire sample sustained that significance. Also, discriminant function analysis was used to compare the predicted librarian subspecialists with actual librarian subspecialists. As a group, 45.20 percent of the librarians could be correctly classified into subspecialty groups according to responses to these adjectival pairs. Academic librarians ( 34.10 percent) were the group least likely to be correctly placed according to the responses given. Finally, five adjectival pairs were combined (coefficient alpha $=0.41$ ) to assess job satisfaction. These pairs included superfluous /indispensable, pessimistic/optimistic, burned-out/interested, underutilized/overworked, and bored /challenged. A mean job satisfaction 
TABLE 3

COMPARISON OF LIBRARIANS CLASSIFIED BY SUBSPECIALTY BY SCORES ON THE "FLEXIBLE-RIGID" PAIR

A) Description of mean scores by librarian subspecialty.

\begin{tabular}{lccc}
\hline Subspecialty & $\overline{\mathrm{X}}$ & SD & N \\
Academic & 1.96 & 0.91 & 174 \\
Public & 1.88 & 0.94 & 157 \\
School & 1.67 & 0.78 & 175 \\
Special & 1.72 & 0.77 & 183 \\
TOTAL & 1.81 & 0.86 & 689 \\
\hline B) Analysis of Variance of scores on the "flexible-rigid" & pair by librarian subspecialty. \\
\hline Source & df & SS & MS \\
between groups & 3 & 9.61 & 3.20 \\
within groups & 685 & 495.71 & 0.72 \\
& $\mathrm{p}<.005$ & & \\
& eta & & \\
\end{tabular}

TABLE 4

COMPARISON OF LIBRARIANS CLASSIFIED BY SUBSPECIALTY BY SCORES ON THE "BUSINESSLIKE-NURTURING" PAIR

A) Description of mean scores by librarian subspecialty.

\begin{tabular}{lccc}
\hline Subspecialty & $\bar{X}$ & SD & N \\
Academic & 2.76 & 1.29 & 169 \\
Public & 2.72 & 1.38 & 150 \\
School & 3.19 & 1.40 & 172 \\
Special & 2.38 & 1.32 & 179 \\
TOTAL & 2.76 & 1.37 & 670 \\
\hline
\end{tabular}

B) Analysis of Variance of scores on the "businesslike-nurturing" pair by librarian subspecialty.

\begin{tabular}{lcccc}
\hline Source & df & SS & MS & F \\
between groups & 3 & 57.32 & 19.11 & 10.56 \\
within groups & 666 & 1204.99 & 1.81 & \\
& $\mathrm{p}<.0001$ & & & \\
& $\mathrm{eta}^{2}=.04$ & & & \\
\hline
\end{tabular}


TABLE 5

JOB SATISFACTION SCORES FOR ACADEMIC LIBRARIANS

\begin{tabular}{lcccccc}
\hline $\begin{array}{l}\text { Level of Satisfaction } \\
\text { (Low to High) }\end{array}$ & 1 & 2 & 3 & 4 & 5 & 6 \\
$\begin{array}{l}\text { Number } \\
\begin{array}{l}\text { Percent of Academic } \\
\text { Librarians }\end{array}\end{array}$ & 0.0 & 0.0 & 3.6 & 31.3 & 59.0 & 6.0 \\
$\begin{array}{l}\text { Percent of Total } \\
\text { Librarian Sample) }\end{array}$ & $(0.0)$ & $(0.3)$ & $(4.4)$ & $(26.2)$ & $(63.4)$ & $(5.7)$ \\
\hline
\end{tabular}

score of 4.7 for the sample affirmed that, overall, the librarians were satisfied with their positions.

\section{Sex-Role Orientation}

Part three of the mailed survey was the Short Form of the Personal Attributes Questionnaire (PAQ), a measure for sexrole orientation. This self-report adjective-rating instrument differentiates stereotypically between the sexes. Its twenty-four bipolar items include eight scales for masculinity (M)-those socially desirable characteristics that more males possess than females; eight scales for femininity (F) - those socially desirable characteristics that more females possess than males; and eight scales for masculinity-femininity (MF)-those characteristics whose social desirability varies among the sexes. Each item is scored $0-4$, with a high score on $\mathrm{M}$ and MF indicating an extreme masculine response and a high F score indicating an extreme feminine response. ${ }^{43}$

A multiple discriminant function analysis was performed on the twenty-four original PAQ variables with the four librarian subspecialties. More than onethird of the total librarian sample could be correctly classified into a subspecialty group by their responses to this third part of the mailed survey. Academic librarians were the most differentiated group - correctly placed 44.7 percent of the time.

All the librarians rated themselves very favorably. This "social desirability response bias" is not uncommon, as all the response options are socially desirable. ${ }^{4}$ For the overall librarian sample, the highest adjusted frequency percentage was at the most favorable anchor on 75 percent of the pairs. Seven pairs of librarian responses, however, fell outside the most favorable response option. Of these seven, five were affective attributes (emotionality, excitability, sensitivity, lamentation, adequacy) frequently associated with women. The homogeneity of the sample on gender, demographics, occupation, and degree of commitment to librarianship as a profession may have caused these results to be slightly skewed.

Normative values for the $\mathrm{M}, \mathrm{F}$, and MF scales were established on a college sample by using a mean of the medians test. ${ }^{45}$ Academic librarians scored above the median for all three subscales. Table 6 compares the academic librarians' scale scores with the scores of the overall sample on the M, F, and MF scales.

The median split method was used to place $M$ and $F$ subscale scores into a $2 \times 2$ $(\mathrm{MxF})$ table. This technique grouped responses into the four sex-role orientation categories of androgynous (high $\mathrm{M}$ high F), masculine (high M low F), feminine (low $\mathrm{M}$ high $\mathrm{F}$ ), and undifferentiated (low M low F). Table 7 presents the percentage of median split classifications by subspecialty for the $\mathrm{M}$ and $\mathrm{F}$ subscales.

In a general sample, "androgynous" and "undifferentiated" would be the most populated cells. For female samples, the expectation is to have high $\mathrm{F}$ and low M scores. Writers have attempted to link position in the $\mathrm{MxF}$ table with self-esteem. When this is done, the androgynous position possesses the greatest self- esteem and the undifferentiated the least. Various theories argue 
TABLE 6

A COMPARISON OF M,F, AND MF SCORES

\begin{tabular}{lccc}
\hline & M & F & MF \\
Median & 21.0 & 23.0 & 15.0 \\
Academic Librarians & 28.0 & 29.0 & 19.0 \\
(Librarian Sample) & $(27.7)$ & $(28.8)$ & $(18.2)$ \\
\hline
\end{tabular}

TABLE 7

PERCENT OF LIBRARIANS IN THE FOUR MASCULINITY AND FEMININITY CATEGORIES BY SUBSPECIALTY

$\mathrm{N}=708$

\begin{tabular}{lcccc}
\hline \multicolumn{4}{c}{$\mathbf{N = 7 0 8}$} \\
& PAQ Categories \\
\hline Academic & Undifferentiated & Feminine & Masculine & Androgynous \\
Public & 24.5 & 29.1 & 20.8 & 25.4 \\
School & 19.0 & 26.5 & 23.4 & 30.0 \\
Special & 17.5 & 26.4 & 23.5 & 32.4 \\
& 20.3 & 23.4 & 26.5 & 29.6 \\
\hline
\end{tabular}

the dispensation of the other two groups. Generally, they fall in-between androgynous and undifferentiated. ${ }^{46}$ For the librarian sample, only the academic librarians rated high on the $\mathrm{F}$ scale.

\section{CONCLUSION}

Roles have been defined as "clusters of norms organized around functions. [They] represent distinct substructures within social positions and statuses, and are situation-specific." 47 The situation specificity of the occupational role of academic librarians-her occupational identity - was the focus of this research. For this project, occupational role identity was separated from the concepts of image or stereotype. Three domains of occupational role identity-personal demographics, orientation to the occupational role, and sex-role orientation -were studied.

Eli Ginzberg et al. identified three themes around which to evaluate occupational choice. These themes-"self," "reality," and "key people" — and an additional theme of "job satisfaction" were used to frame this study. ${ }^{48}$ Within the structural theme of "self," academic librarians in this study were white, Protestant, middle-aged, married women with no children. They were experienced in the profession as well as in their subspecialty. In terms of "reality"-those factors descriptive of training, preparation for, and the actual practice of the career-the academic librarians were summarized as achieving an M.L.S. in 1971 at one of three library schools. Pay seemed to be an issue and was the factor most likely to cause them to move to another profession. The academic librarians in the sample were well educated, pursuing studies beyond their library degrees. Sampled academic librarians welcomed the challenge of academic librarianship. In terms of "key people,"mentors and family-they were the progeny of professional parents who probably encouraged them directly or by example to become professional women. The absence of children in their lives afforded them the time to succeed in the rigorous demands of academic librarianship. The fourth element, "job satisfaction," found the academic librar- 
ians satisfied with their positions, with the exception of pay.

Orientation to the occupational role was the second domain of occupational role identity studied. Academic librarians were enthusiastic about their role identity, as evidenced by the clustering of responses around the most favorable options. However, they were somewhat more moderate in their enthusiasm than their counterparts in the other three subspecialties. While school librarians (60.5 percent) were the most predictable in their responses, academic librarians were the least predictable ( 34.10 percent). Four possible explanations for this are the "organizational structure of the library," the "clientele," the "specialization" available, and "certification."

"Organizational structure of the library" includes the size and type of the organization, the relationship of the library to the organization, and the relationship of the library program to the curriculum. Academic libraries encompass a wide variety of institutional foci (junior college, college, university, and research) with concomitant complexities in the organization of the host institution. While the primary relationship of the library to the host is clearly defined as supporting the curriculum, academic libraries must also support the research and service mandate of the faculty.

With a national emphasis on adult education and the entry of retired adults into colleges and universities, academic libraries may support a clientele ranging from the thirteen-year-old gifted student to elderly adults. Academic libraries also support the lifelong learning needs of their constituents.

Academic librarians may be characterized as the most decisive, the most excitable in a major crisis, and the most gentle.

"Specialization" in academic libraries introduces a large element of uniqueness to the subspecialty. Areas such as reference, cataloging, collection develop- ment, serials, and database management require flexible thinking and specialized knowledge. In addition, graduate degrees and advanced training, elements that set the academic librarians apart, have introduced areas of specialization within the profession.

Generally, academic librarians do not have rigorous certification requirements. "Certification" would introduce a common knowledge base and a philosophical homogeneity into the subspecialty which academic librarians do not now generally possess. This domain of occupational identification most clearly differentiated between the subspecialties. As such, it showcased the modern academic librarian as a person who daily copes in an arena much broader than that of her colleagues in the other three types of libraries. Further, it confirms the existence of a unique occupational identity/subspecialty for academic librarians.

The final aspect of occupational role identity considered was sex-role orientation. This was included because of the numerical predominance of women in the field and raises issues of occupational power. Historically, professions with a numerical dominance of women have been segregated from a power base. Two of the traditional explanations cited are the service relationship to the clientele and the lack of life-death decisionmaking requirements. ${ }^{49}$ Other reasons for including sex-role orientation in a discussion of the librarian's occupational identity are the librarian's alleged weak orientation to autonomy, the theory that the increase of homosexual men into librarianship is linked to fulfillment of the female role, and the overall image of the librarian as somehow deficient in feminine attributes..$^{50,51}$ Based on research using the Short Form of the PAQ, academic librarians may be characterized as the most decisive, the most excitable in a major crisis, and the most gentle. They had the highest F score of the total sample.

With their educational background, commitment to continuing education, and role strengths, these women 
strongly answer the question "Why academic librarianship?" Academic librarianship is an evolving profession which requires adaptability and commitment. These academic librarians show they have the adaptability - particularly with regard to the organization of the library, clientele, and specializations - and commitment to lead their institutions into the next century. The academic librarians represented in the survey blended their interests nicely with the enormous and diverse demands of their occupational role.

\section{REFERENCES AND NOTES}

1. Kathleen M. Heim, ed., The Status of Women in Librarianship, (New York: Neal-Schuman, 1983), p. 1.

2. Pauline Wilson, Stereotype and Status (Westport, Conn.: Greenwood, 1982), passim.

3. Patricia Glass Schuman, "The Image of Librarians: Substance or Shadow?," Journal of Academic Librarianship 16:86-89 (May 1990).

4. George Ritzer, Working (Englewood Cliffs, N.J.: Prentice-Hall, 1977), p.96.

5. See, for example, Gerald Thielbar and Saul D. Feldman, "Occupational Stereotypes and Prestige," Social Forces 48:64-72 (May 1969); Douglas M. More and Robert W. Suchner, "Occupational Situs, Prestige, and Stereotypes," Sociology of Work and Occupations 3:169-186 (May 1976); Albert J. Reiss, Jr., Occupations and Social Status (New York: Arno, 1977); and The Role of Women in Librarianship 1876-1976 ed. Kathleen Weibel, Kathleen M. Heim, and Dianne J. Ellsworth (Phoenix, Ariz.: Oryx, 1979),passim.

6. Beverly P. Lynch, "A Comment on the Role of the Academic Librarian," Journal of Academic Librarianship 4:134-35 (July 1978).

7. See, for example, Geraldine Beaty King, "Attitudes of Library School Students Towards Reference Librarians and Library Information Service" (Ph.D. diss., Univ. of Minnesota, 1971); Malcom H. Brantz, "Graduate Student's Attitudes Toward Librarians and Specialists," California School Libraries 47:28-33 (Fall 1975); U. Bloch and T. Bloch, "Occupational Perceptions of Librarians by High School Students," Library Quarterly 51:292-300 (July 1981).

8. See, for example, Marion Anthony Milczewski, "Personality Rating of Library School Students" (Master's thesis, Univ. of Illinois, 1940); Agnes L. Reagan, A Study of Factors Influencing College Students To Become Librarians (Chicago: Assoc. of College and Research Libraries, 1958); Anne McMahon, The Personality of the Librarian (Adelaide: Libraries Board of South Australia, 1967); Patricia Ann Reeling, "Undergraduate Female Students as Potential Recruits to the Library Profession" (Ph.D. diss., Columbia Univ., 1969); and Patrick B. Forsyth and Thomas J. Danisiewicz, "Toward a Theory of Professionalization," Work and Occupations 12:59-76 (Feb. 1985).

9. See, for example, Anita R. Schiller, Characteristics of Professional Personnel in College and University Libraries (Washington, D.C.: U.S. Department of Health, Education, and Welfare, Office of Education, Bureau of Research, 1968); Michael D. Cooper, "A Statistical Portrait of Librarians: What the Numbers Say," American Libraries 7:327-30 (June 1976); Leigh S. Estabrook and Kathleen M. Heim, "A Profile of ALA Personal Members," American Libraries 11:654-59 (Dec. 1980); Mark E. Cain, "Academic and Research Librarians: Who Are We?" Journal of Academic Librarianship 14:292-96 (Nov. 1988).

10. See, for example, Robert Raymond Douglass, "The Personality of the Librarian" (Ph.D. diss., Univ. of Chicago, 1957); Perry D. Morrison, The Career of the Academic Librarian (Chicago: American Library Assoc., 1969); Howard Clayton, "Femininity and Job Satisfaction Among Male Library Students at One Midwestern University," College $\mathcal{E}$ Research Libraries 31:388-98 (Nov. 1970); David L. Lee and Janet E. Hall, "Female Library Science Students and the Occupational Stereotype: Fact or Fiction?," College \& Research Libraries 34:265-67 (Sept. 1973); and Peter Hernon and Maureen Pastine, "Student Perceptions of Academic Librarians," College \& Research Libraries 38:129-139 (March 1977).

11. Wilson, Stereotype and Status, p.41-68.

12. Alice I. Bryan, The Public Librarian (New York: Columbia Univ. Press, 1952), passim.

13. Robert Benjamin Clift, "The Personality and Occupational Stereotype of Public Librarians" (Ph.D. diss., Univ. of Minnesota, 1976), passim. 
14. Rosalee McReynolds, "A Heritage Dismissed," Library Journal 110:25-31 (Nov. 1985).

15. Locke J. Morrisey and Donald O. Case, "There Goes My Image: The Perception of Male Librarians by Colleague, Student, and Self," College \& Research Libraries 49:453-64 (Sept. 1988).

16. Pamela J. Cravey, "Focusing on the Librarian: Are Librarians Selling Themselves?" Georgia Librarian 27:28-31 (Summer 1990).

17. Donald P. Warwick and Charles A. Lininger, The Sample Survey (New York: McGraw Hill, 1975), p.129.

18. Seymour Sudman, Applied Sampling (New York: Academic Press, 1976), p.107.

19. Charles H. Backstrom and Gerald Hursh-Cesar, Survey Research (New York: Wiley, 1981), p.68.

20. Sudman, Applied Sampling, p.111.

21. George Psathas, "Toward a Theory of Occupational Choice for Women," Sociology and Social Research 52:253-68 (Jan. 1968).

22. Victor R. Fuchs, Women's Quest For Economic Equality (Cambridge, Mass.: Harvard Univ. Press, 1988), p.8.

23. For representative studies see, for example, Studs Terkel, Working (New York: Pantheon, 1972), passim; Charles Eugene Bujold, "The Role of Self-Concepts, Occupational Concepts, and Reality Considerations in the Occupational Choice of French-Canadian Secondary School Boys" (Ed.D. diss., Teachers College, Columbia Univ., 1972), passim; Anne Roe, The Psychology of Occupations (New York: Wiley, 1956), passim; Anne Roe, "Early Determinants of Vocational Choice," Journal of Counseling Psychology 4:212-17 (1957); Anne Roe and M. Siegelman, The Origin of Interests (Washington, D.C.: American Personnel and Guidance Association, 1964), passim; Richard B. Freeman, The Market for College-Trained Manpower: A Study in the Economics of Career Choice (Cambridge, Mass.: Harvard Univ. Press, 1971), passim; F. Kuder, Activity Interests and Occupational Choice (Chicago: Science Research Associates, 1977), passim; and John Saltiel, "The Wisconsin Model of Status Attainment and the Occupational Choice Process," Work and Occupations 15:334-55 (Aug. 1988).

24. See, for example, David L. Klemmack and John N. Edwards, "Women's Acquisition of Stereotyped Occupational Aspirations," Sociology and Social Research 57:510-25 (1973); P. W. Musgrave, "Towards a Sociological Theory of Occupational Choice," Sociological Review 15:33-46 (March 1967); and M. Kh. Titma, "The Choice of Occupation as a Social Problem," Soviet Sociology 16:3-19 (Summer 1977).

25. For examples of a variety of subjects of study see Eli Ginzberg, and others, Occupational Choice (New York: Columbia Univ. Press, 1951); Hidden Aspects of Women's Work, ed. Christine Bose, Roslyn Feldberg and Natalie Sokoloff (New York: Praeger, 1987); P. A. O'Reilly, "Predicting the Stability of Expressed Occupational Choices of Secondary Students" (Ph.D. diss., Pennsylvania State Univ., 1973); and Frank Echols, Jr., "Occupational Aspirations, Expectations and Deflection Level of Junior College Occupational Students" (Ph.D. diss., Univ. of Georgia, 1975).

26. For examples of these models see, Peter M. Blau and others, "Occupational Choice: A Conceptual Framework," Industrial und Labor Relations Review 9:532-43 (July 1956); Psathas "Toward a Theory," p. 253-68 ; Samuel H. Osipow, Theories of Career Development (New York: Appleton-Century-Crofts, 1973), passim.

27. For examples of occupational aspirations see, William P. Kuvlesky and Robert C. Bealer, "AClarification of the Concept' Occupational Choice,'" Rural Sociology 31:265-76 (Sept. 1966); Edward S. Jones, "Relation of Ability to Preferred and Probable Occupation," Educational Administration and Supervision 26:220-26 (Mar. 1940); E. Donald Sisson, "Vocational Choices of College Students," School and Society 46:765-68 (Dec. 1937).

28. For examples of the applications of these dichotomies see, Terence R. Mitchell and Lee Roy Beach, "A Review of Occupational Preference and Choice Research Using Expectancy Theory and Decision Theory," Journal of Occupational Psychology 49:231-48 (1976); H. Lytle Givens and Albeno P. Garbin, "Social-Personal Characteristics and Occupational Choice Processes of Female Flight Attendants," Vocational Guidance Quarterly 26:116-24 (Dec. 1977); Jacqueline Miles Boles, "The Nightclub Stripper: A Sociological Study of a Deviant Occupation" (Ph.D. diss., Univ. of Georgia, 1973).

29. Osipow, Theories of Career Development, p.10-11.

30. Ronald M. Pavalko, Sociology of Occupations and Professions (Itasca, Ill.: Peacock, 1971), p.45. 
31. Musgrave, "Towards a Sociological Theory of Occupational Choice," p.34-35; Margaret A. Coulson and others, "Towards a Sociological Theory of Occupational Choice-A Critique," Sociological Review 15:301-09 (Nov. 1967); and Julienne Ford and Steven Box, "Sociological Theory and Occupational Choice," Sociological Review 15:287-99 (Nov. 1967).

32. For examples see, Donna M. Douglass, Choice and Compromise (New York: ANACON, 1983), passim; and Marilyn Fabe and Norma Wikler, Up Against the Clock (New York: Random, 1979), passim.

33. Louise Vetter, "Career Counseling For Women," in Career Development and Counseling of Women, ed. L. Sunny Hansen and Rita S. Rapoza (Springfield, Ill.: Thomas, 1978), passim.

34. Charles E. Osgood, George J. Suci, and Percy H. Tannenbaum, The Measurement of Meaning (Urbana: Univ. of Illinois Press, 1975), p. 325.

35. See, for example, Ann B. Pratt, "Exploring Stereotypes of Popular and Unpopular Occupations Among Women-in-General," Journal of Vocational Behavior 6:145-64 (Apr. 1975); Gwendolyn Hankerson Willis, "The Effect of Occupational Stereotypes and the Self-Perceptions of College Women, Traditionalists and Non-Traditionalists, on Occupational Choice" (Ph.D. diss., Georgia State Univ., 1977), passim; and Morrisey and Case, "There Goes My Image," p. 453-60.

36. Edwin E. Ghiselli, John P. Campbell, and Sheldon Zedeck, Measurement Theory for the Behavioral Sciences (San Francisco: W. H. Freeman, 1981), p.209.

37. Janet T. Spence and R. L. Helmreich, Masculinity and Femininity (Austin, Tex.: Univ. of Texas Press, 1978), p.19.

38. Ibid., p.32-33.

39. Ritzer, "Working," p.132.

40. While his subjects were selected in a much different way but at about the same time, Cain's demographic study of academic librarians yielded similar results.

41. See, for example, Donald C. Reitzes, "The College Student Role/Identity: Processes and Consequences" (Ph.D. diss., Indiana Univ., 1977); Jeylan T. Mortimer and Jon Lorence, "Occupational Experience and the Self-Concept: A Longitudinal Study," Social Psychology Quarterly 42:307-23 (1979).

42. Osgood, Suci, and Tannenbaum, Measurement of Meaning, p.88.

43. Spence and Helmreich, Masculinity and Femininity, p.31-32.

44. Ibid., p.34-35.

45. Ibid., p.33-36.

46. Janet T. Spence, Robert Helmreich and Joy Stapp, "Ratings of Self and Peers on Sex Role Attributes and Their Relation to Self-Esteem and Conceptions of Masculinity and Femininity," Journal of Personality and Social Psychology 32:29-39 (1975).

47. Frederick L. Bates and Clyde C. Harvey, The Structure of Social Systems (New York: Gardner, 1975), p.91.

48. Ginzberg and others, Occupational Choice, p.52.

49. See, for example: Valerie Kincade Oppenheimer, "The Sex Labeling of Jobs," Industrial Relations 7:219-34 (1968); Ritzer, "Working,"p. 179-88 and 329-56; The Status of Women in Librarianship, passim; Michael F. Winter, The Culture and Control of Expertise (Westport, Conn.: Greenwood, 1988).

50. Arnold Hirshon, "What's in a Name?" Michigan Librarian 43:4-5 (1977).

51. Dee Garrison, "The Tender Technicians: The Feminization of Public Librarianship, 1876-1905," Journal of Social History 6:131-59 (1972-1973). 